\title{
APLIKASI SENSOR NTC 47D-15 DAN SENSOR KELEMBABAN 808H5V5 PADA MESIN PENGERING DAUN SUNGKAI
}

Oleh :

\section{Pola Risma}

\author{
Staf Pengajar Jurusan Teknik Elektro Politeknik Negeri Sriwijaya Palembang \\ e-mail : polarisma43@yahoo.com
}

\begin{abstract}
Nowdays, the production of herbal medicines to industrial scale household progressively increased as the emergence of the phenomenon in the society for the re-use of natural medicines / herbal derived from plants as one solution to health. In order for the herbal medicines are not easily damaged and can be stored for a long time, the drying process is carried out at a temperature of 300C-90oC (Depkes RI, 1985). The herbal medicine used in this study is the Sungkai leaves which is dried using dryer that applies NTC temperature sensor 47D-15, 808H5V5 humidity sensors, and microcontroller ATMega 8535. NTC sensor 47D-15 serves to detect the temperature to be set at the desired range during the drying process occurs while the humidity sensor 808H5V5 detects moisture of Sungkai leaves after the drying process.
\end{abstract}

Keywords : NTC sensor 47D-15, Humidity sensor 808H5V5, Microcontroller ATMega 8535, Sungkai leaves

\section{PENDAHULUAN}

\section{Latar Belakang}

Saat ini muncul fenomena di masyarakat secara luas yang kembali memakai obat alamiah/herbal yang berasal dari tumbuh-tumbuhan sebagai solusi bagi kesehatan, karena obat herbal tersusun oleh bahan-bahan organik yang kompleks dan tidak menimbulkan efek samping yang berbahaya bagi tubuh jika di konsumsi sesuai dengan takaran. Obat tradisional tidak sulit untuk ditemukan karena berasal dari alam, terutama jika kita dapat menanam sendiri dengan membuat tanaman obat keluarga (TOGA) yang meliputi tanaman untuk pengobatan dan pemeliharaan kesehatan. Harga Akan meningkat jika obat herbal itu diperoleh dalam bentuk simplisia yang dikeringkan dan akan meningkat lagi jika dikonsumsi dalam bentuk teh atau kapsul, bahkan akan menjadi cukup tinggi jika dalam bentuk ekstrak.

Adapun syarat untuk dapat memperoleh bentuk simplisia adalah harus bebas serangga, fragmen hewan, kotoran hewan, tidak boleh menyimpang dari bau, warna, tidak boleh mengandung lendir, cendawan, tidak boleh mengandung bahan lain yang beracun atau berbahaya serta kadar abu yang tidak larut dalam asam maksimal $2 \%$.

Pengeringan dilakukan agar memperoleh simplisia yang tidak mudah rusak, sehingga dapat disimpan dalam waktu yang lama. (http://farmasibahanalam.com).

Pengeringan dapat dilakukan dengan dua cara, yaitu pengeringan secara alami dan secara buatan. Pengeringan alami 
dilakukan dengan memanfaatkan sinar matahari baik secara langsung maupun ditutupi dengan kain hitam. Sedangkan pengeringan secara buatan dilakukan dengan bantuan oven. Suhu terbaik pengeringan adalah $60 \mathrm{oC}$.

(http://farmasibahanalam.com/2010/ 08/5-a-penyiapan-bahan-baku-16-25).

\section{Permasalahan}

Pada penelitian ini permasalahan yang dibahas adalah aplikasi NTC 47D15 sebagai sensor pendeteksi suhu dan sensor $808 \mathrm{H} 5 \mathrm{~V} 5$ sebagai pendeteksi kelembaban daun Sungkai pada mesin pengering daun Sungkai yang sesuai dengan standar Depkes RI.

\section{Tujuan dan Manfaat}

Penelitian ini bertujuan untuk mempelajari prinsip kerja sensor NTC (Negative Temperature Coeficient) 47D15 sebagai pendeteksi suhu dan sensor 808H5V5 sebagai pendeteksi kelembaban daun Sungkai pada mesin pengering daun Sungkai.

Sedangkan manfaat dari penelitian ini untuk mengetahui prinsip kerja sensor NTC (Negative Temperature Coeficient) sebagai pendeteksi suhu pada mesin pengering daun sungkai. Mengetahui prinsip kerja sensor 808 H5V5 sebagai pendeteksi kelembaban daun Sungkai pada mesin pengering daun Sungkai.

\section{Metode Pembahasan}

Metode pembahasan pada penelitian ini menggunakan metode rancang bangun, menggunakan metode literature, serta melakukan pengujian dan analisa dari fungsi komponen NTC 47D-15 dan Sensor kelembaban 808H5V5. Dari analisa dapat dibuat rangkuman berdasarkan hasil pengujian yang telah dilakukan.
TINJAUAN PUSTAKA

Negative Temperature Coeficient (NTC) 47D-15

$\begin{array}{ccr}\text { Negative } & \text { Temperature } & \text { Coeficient } \\ \text { (NTC) } & \text { merupakan } & \text { resistor }\end{array}$ yang mempunyai koefisien temperatur negatif yang sangat tinggi. NTC jenis ini dibuat dari oksida logam seperti mangan, nikel, besi, tembaga dan titanium. Oksida logam ini sebenarnya mempunyai resistansi yang tinggi, tetapi dapat diubah menjadi bahan semikonduktor dengan menambahkan beberapa ion lain (sebagai doping) yang mempunyai valensi yang berbeda, sedangkan perubahan resistansi pada NTC karena pengaruh perubahan temperature.

(http://elektronika-

dasar.web.id/komponen/sensor-

tranducer/sensor-suhu-termistor/, diakses pada 3 Jui 2013 pukul 21.15)

NTC 47D-15 memiliki R sebesar 47

dengan suhu operasional $-55^{\circ} \mathrm{C}$ $200^{\circ} \mathrm{C}$ dan toleransi tahanan $10 \%$. NTC bersifat resistif, nilai $\mathrm{R}$ akan berubah sesuai dengan perubahan temperature, dimana nilai R-nya akan menurun apabila temperatur disekelilingnya naik.

(http://www.scribd.com/doc/761065

63/3a-47r-ntc-therm-is-tor-47d-15variable-resistor, diakses pada 3 Jui 2013 pukul 21.15)
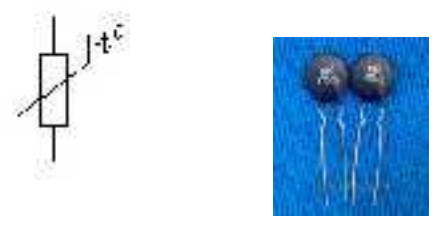

(a)

(b)

Gambar 2.1 (a) Simbol NTC \& (b) Bentuk fisik NTC (http://elektronika-dasar.web.id/wpcontent/uploads/2012/01/Termistor.jpg diakses pada 3 Jui 2013 pukul 21.15) 
NTC bekerja dengan cara mendeteksi besaran fisis berupa suhu yang kemudian dikonversikan ke besaran listrik berupa tegangan (volt) menggunakan perbandingan temperatur yang bergantung dengan resistansinya. Sebuah NTC awalnya memiliki nilai resistansi yang tinggi untuk membatasi arus yang mengalir, saat mendeteksi panas nilai resistansinya akan menurun seiring bertambahnya.

(http://www.ehow.com/facts_7492418_n tc-thermistor-work.html, diakses pada tanggal 14 Juli 2013, pukul 23.30)

\section{Sensor Kelembaban 808H5V5}

Sensor kelembaban 808H5V5 adalah sensor yang digunakan untuk mentedeksi kelembaban uap air yang terkandung dalam udara ataupun benda, melalui perubahan kelembaban yang terjadi karena kenaikan temperature sebagai akibat berubahnya kadar air karena penguapan.

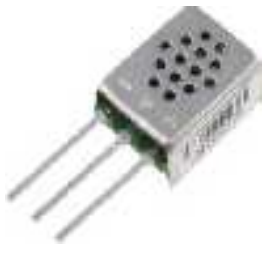

\section{Gambar 2.2 Sensor Kelembaban 808H5V5}

Sensor kelembaban 808H5V5 adalah sensor kelembaban berbasis kapasitif yang merubah besaran kelembaban menjadi

(www.meriwardanaku.com)

tegangan.

Spesifikasi dari sensor kelembaban 808H5V5 adalah

- Bekerja pada tegangan 5 volt DC

- Range kelambaban yang diukur 0$100 \%$ RH

- Keakuratan $\leq \pm 4 \% \mathrm{RH}$

- Tegangan keluaran 0.8-3.9 volt
Prinsip kerja sensor kelembaban 808H5V5 sama dengan prinsip kerja kapasitor air-filled (terisi-udara), yaitu dengan mendeteksi besarnya kelembaban relatif udara atau benda di sekitar sensor kemudian sensor 808H5V5 akan mengkonversi besaran kelembaban ke dalam bentuk tegangan listrik dimana kapasitansi suatu sensor sebanding dengan kelembaban relative.

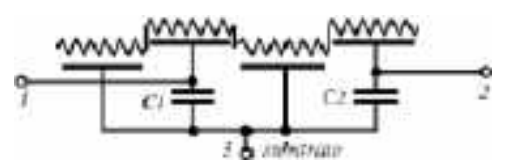

Gambar 2.3 Rangkaian Listrik Ekivalen Sensor Kelembaban

Rangkaian listrik ekuivalen sensor kelembaban masing-masing bagiannya mewakili jalur transmisi RC, ketika kelembaban relatif naik maka resistansi permukaan akan turun dan kapasitansi antara terminal 1 dan 2 akan naik.

(http://www.scribd.com/doc/139099985/ Sensor-Kelembaban diakses pada 14 juli 2013 pukul 00:13 WIB)

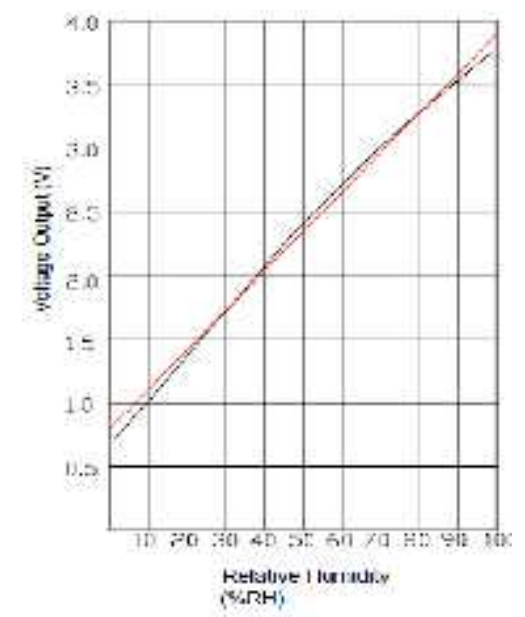

Gambar 2.4 Grafik Karakeristik Perubahan Output terhadap Kelembaban

Keterangan : Garis Merah $=$ Tegangan Garis Hitam =

Kelembaban 
Tabel 2.1 Data respon kelembaban terhadap output pada tegangan 5 volt

\begin{tabular}{|c|c|c|c|c|}
\hline 10:3E & Mor & freg & $2 \% 83$ & 6NOA KGRE SCPE \\
\hline 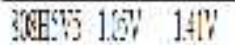 & $173 \mathrm{Y}$ & 2003 & $2+\pi$ & 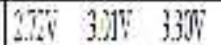 \\
\hline
\end{tabular}

\section{Mikrokontroler ATMega 8535}

Mikrokontroler

ATMega8535 merupakan mikrokontroler 8 bit teknologi CMOS dengan konsumsi daya terendah yang berbasis arsitektur enchanced RICS (Reduced Instruction Set Computer) AVR. Dengan eksekusi instruksi yang sebagian besar hanya menggunakan satu siklus clock, ATMega 8535 mencapai throughput sekitar 1 MIPS per $\mathrm{MHz}$ yang mengizinkan perancangan sistem melakukan optimasi konsumsi daya versus kecepatan pemrosesan.

Konfigurasi pin mikrokontroler ATMega8535 untuk 40 pin DIP (Dual In Line Package) ditunjukkan pada gambar 2.5 berikut:

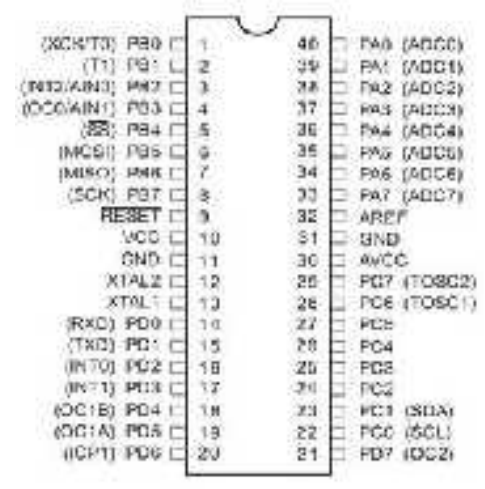

Gambar 2.5 Konfigurasi Pin Mikrokontroler Atmega8535

Mikrokontroler AVR Atmega memiliki 40 pin diantaranya digunakan sebagai Port paralel. Operasi port pada mikrokontroler ATMega8535 dapat difungsikan sebagai input atau sebagai output dengan keluaran high dan low. Dalam mengatur fungsi port I/O apakah sebagai input atau output maka diperlukan setting pada register DDR dan port. (Syahrul. 2012. Mikrokontroler AVR ATMEGA 8535. Bandung: Informatika).

\section{Analog Digital Converter (ADC)}

Analog Digital Converter (ADC) merupakan salah satu fitur yang terdapat pada mikrokontroler ATMega 8535 dengan 8 buah masukan analog yang memiliki resolusi hingga 10 bit. Tegangan alnalog $0-5$ volt akan dikodekan menjadi salah satu dari 1024 representasi biner antara $000 \mathrm{H}-3 \mathrm{FFH}$. (Syahrul. 2012. Mikrokontroler AVR ATMEGA 8535. Bandung: Informatika).

Nilai digital sinyal masukan ADC dapat dihitung dengan persamaan 2.1

$$
\text { Nilai ADC }=\frac{V}{v} \times 1024 \ldots \ldots \ldots
$$

Dimana :

Vin = tegangan input/ sinyal analog Vref $=$ tegangan referensi $(5$ volt $)$ $1024=$ Nilai resolusi ADC pada ATMega 8535

\section{Transistor Sebagai Switching}

Selain digunakan sebagai penguat, transistor juga digunakan sebagai saklar (switching). Untuk mendapatkan kondisi on/off seperti pada saklar, transistor dioperasikan pada salah satu titik kerjanya, titik saturasi atau cut off. Titik saturasi transistor adalah daerah kerja transistor dimana arus kolektor mencapai nilai maksimum.(http://elektronikadasar.web.id/teori-elektronika/daerahsaturasi-transistor/diakses pada 14 Juli 2013, pukul 12.35)

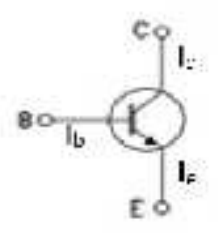

Gambar 2.6 simbol Transistor

Jika transistor diberi arus pada basis (Ib), maka transistor berada dalam 
keadaan saturasi sehingga transistor bekerja sebagai sebuah saklar tertutup, karena arus akan mengalir dari kolektor (Ic) ke emiter (Ie). Jika transistor tidak diberi arus pada basis (Ib), maka transistor berada dalam keadaan cut off, sehingga transistor akan bekerja sebagai saklar terbuka karena arus tidak mengalir dari kolektor (Ic) ke emiter (Ie).

(http://elektronikadasar.org/mengetahuifungsi-transistor-sebagai-saklar/ diakses pada 14 Juli 2013, pukul 12.35)

\section{Relay Single Pole Double Throw (SPDT) ZND}

Relay Single Pole Double Throw (SPDT) ZND merupakan relay yang terdiri dari sebuah kontak NO, sebuah kontak NC serta sebuah COMMON. Pada saat kumparan tidak dialiri arus, maka kontak NC akan terhubung dengan COMMON. Jika kumparan dialiri arus, maka kontak akan bergerak dari NC ke NO, sehingga NO akan terhubung dengan COMMON.

(http://telinks.com/tag/relay-spdt/

diakses pada tanggal 15 Juli 2013 pukul 21.00)

Spesifikasi Relay SPDT tipe ZND:

- Frekuensi $=50 / 60 \mathrm{~Hz}$

- Input tegangan $=6$ Volt DC

- Output $\mathrm{AC}=250 \mathrm{~V}, \mathrm{I}=7 \mathrm{~A}$

$$
\mathrm{AC}=125 \mathrm{~V}, \mathrm{I}=10 \mathrm{~A}
$$

- Output DC $=125 \mathrm{~V}, \mathrm{I}=10 \mathrm{~A}$ $\mathrm{DC}=28 \mathrm{~V}, \mathrm{I}=10 \mathrm{~A}$

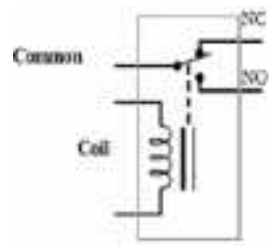

Gambar 2.7 Konstruksi Rangkaian Relay SPDT

\section{Driver Motor}

Driver motor digunakan sebagai penggerak motor power window agar dapat berputar searah jarum jam atau berlawanan arah jarum jam. Driver motor power window menggunakan transistor darlington, yaitu rangkaian elektronika yang terdiri dari sepasang transistor bipolar (dwi kutub) yang tersambung secara seri untuk mendapatkan penguatan yang tinggi, karena hasil penguatan transistor pertama akan dikuatkan lebih lanjut pada transistor yang kedua.

(id.wikipedia.org/wiki/transistor_darling ton, tanggal 15 Juli 2012, pukul 00.11)

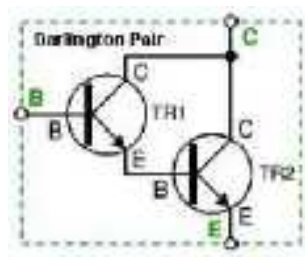

Gambar 2.8 Rangkaian Darlington

\section{Motor DC Power Window}

Power window merupakan salah satu jenis motor DC yang mempunyai torsi tinggi dengan tegangan input 12 VDC dan dilengkapi dengan internal gearbox untuk memudahkan dalam instalasi mekanik. Motor DC Power Window menggunakan tegangan searah sebagai sumber tenaganya, yang mengubah energi listrik searah menjadi mekanis berupa tenaga penggerak torsi. Motor akan berputar pada satu arah bila diberi polaritas tegangan dan bila polaritas dari tegangan tersebut dibalik maka arah putaran motor akan terbalik. (http://www.meriwardanaku.com/2011/1 1/prinsip-kerja-motor-arus-searahdc.html diakses diakses pada tanggal 15 Juli 2013 pukul 21.00 WIB)

Spesifikasi Motor Power Window :

- Bekerja Pada tegangan 12 Volt DC

- Range temperature : $-30^{\circ} \mathrm{C}$ sampai $80^{\circ} \mathrm{C}$

- Kecepatan : $40 \pm 5 \mathrm{rpm}$

- Beban : 4 Nm 
(http://www.scribd.com/doc/97291557/P ower-Window diakses pada tanggal 4 Juli 2013 pukul 22.30 WIB)

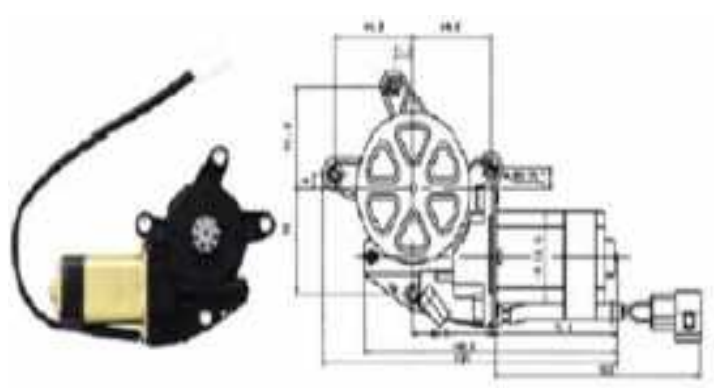

Gambar 2.9 Motor DC Power Window

\section{Elemen Pemanas (Heater)}

Elemen pemanas merupakan material konduktor yang dapat menghantarkan panas yang diaktifkan secara elektrik dengan memberikan suplay tegangan. Panas yang dihasilkan elemen pemanas listrik ini bersumber dari kawat atau pun pita bertahanan listrik tinggi yang dialiri arus listrik pada kedua ujungnya dan dilapisi oleh isolator listrik.

Karakteristik dari elemen pemanas adalah :

- Merupakan material yang bersifat konduktor listrik

- Mendapatkan suplay dari listrik melalui kontak.

- Mechanical support

- Material yang solid.

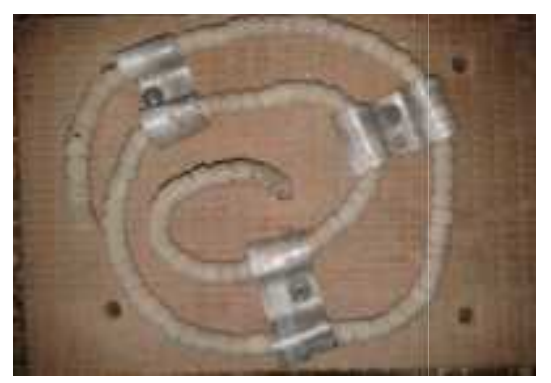

Gambar 2.10 Elemen Pemanas (Heater)

Spesifikasi Elemen Pemanas

(Heater) :

- Tegangan $220 \mathrm{~V}$

- Daya umumnya 450 watt
- Menghasilkan suhu $>150^{\circ} \mathrm{C}$

(www.elemenpemanas.co.id diakses pada tanggal 7 juli 2013 pukul 14.35 WIB)

\section{Liquid Crystal Display (LCD)}

Liquid Crystal Display (LCD) merupakan sebuah teknologi layar digital yang menghasilkan citra pada sebuah permukaan yang rata (flat) dengan memberi sinar pada kristal cair dan filter berwarna, yang mempunyai struktur molekul polar, dan diapit antara dua elektroda yang transparan.

Sebuah LCD dibentuk oleh suatu jenis cairan khusus yang ditempatkan diantara dua buah lempengan kaca dimana terdapat sebuah bidang latar (backplane) yang merupakan lempengan kaca bagian belakang, dengan sisi dalam yang ditutupi oleh lapisan elektroda transparan. Dalam keadaan normal, cairan yang digunakan memiliki warna cerah, ketika diberi tegangan daerahdaerah tertentu pada cairan akan berubah warnanya menjadi hitam. LCD dapat menampilkan karakter berupa angka, huruf, dan simbol. (Owen Bishop :158)

Spesifikasi Liquid Crystal Display (LCD):

- Bekerja pada tegangan 5 volt

- Terdapat 16 x 2 karakter huruf yang bisa ditampilkan.

- Setiap huruf terdiri dari 5x7 dotmatrix cursor.

- Terdapat 192 macam karakter.

- Terdapat 80 × 8 bit display RAM (maksimal 80 karakter).

- Memiliki kemampuan penulisan dengan 8 bit maupun dengan 4 bit. (Syahrul, 2012 : hal 238-239)

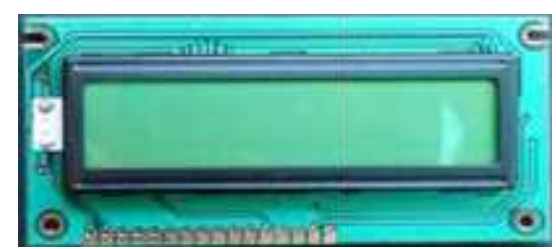

ambar 2.11 Bentuk Fisik Liquid Crystal Display (LCD) 16 Karakter X 2 Baris 
Tabel 2.2 Keterangan Konfigurasi Pin Liquid Crystal Display (LCD)

\begin{tabular}{|c|c|c|c|}
\hline Phano & Symbol & Lonel & Description \\
\hline 1 & vSS & $\mathrm{W}$ & Ground \\
\hline 2 & VDO & 5V & Supphy votage fer loge \\
\hline 3 & vo & (Varatio) & Operang volage for $t C D$ \\
\hline 4 & RS & KL & H: Dath L Instructon cedn \\
\hline 3 & RW & $\mathrm{HL}$ & H-Reod L: Wrbe \\
\hline 8 & E & $H, H \rightarrow X_{2}$ & Chip Enable signes \\
\hline 7 & $\mathrm{DeO}$ & $\mathrm{HL}$ & Data be 0 \\
\hline 8 & $D a 1$ & $\mathrm{HL}$ & Data be : \\
\hline 0 & De2 & $\mathrm{HL}$ & Doseber. \\
\hline 10 & 083 & HL & Oonabr3 \\
\hline$\pi$ & DE4 & $\mathrm{HL}$ & Data be 4 \\
\hline 12 & Des & $\mathrm{HL}$ & Data be 5 \\
\hline 13 & De8 & $n L$ & Data be 8 \\
\hline 14 & Da7 & n! & Deata be ? \\
\hline 15 & A & $4,2-46 \mathrm{~V}$ & ED. \\
\hline 16 & $k$ & QV & IED. \\
\hline
\end{tabular}

\section{METODOLOGI}

\section{Blok Diagram}

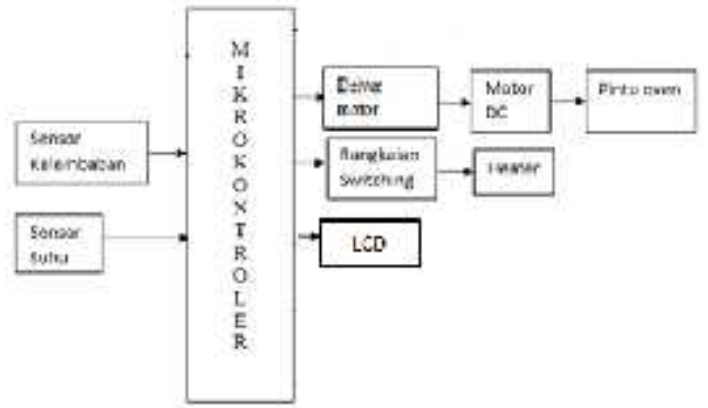

Gambar 3.1 Blok Diagram Sistem

Prinsip Kerja Mesin Pengering Daun Sungkai

Pada mesin pengering daun Sungkai, daun Sungkai diletakan pada suatu wadah kemudian dimasukan ke dalam oven secara manual dengan menekan switch untuk membuka pintu oven. Setelah pintu oven menutup heater ON, proses pengeringan terjadi. Selama proses pengeringan, jika suhu oven yang terdeteksi oleh NTC $>40^{\circ} \mathrm{C}$, maka mikrokontroler meng-OFF-kan heater. Ketika suhu oven $<40^{\circ} \mathrm{C}$, maka heater akan kembali ON.

Sensor kelembaban akan mendeteksi kelembaban objek, jika kelembaban sudah mencapai set point yang telah ditetapkan (51\%), maka heater akan OFF, oven akan kembali membuka secara otomatis. Suhu dan Kelembaban yang terdeteksi akan ditampilkan pada LCD.

\section{Gambar Rangkaian}

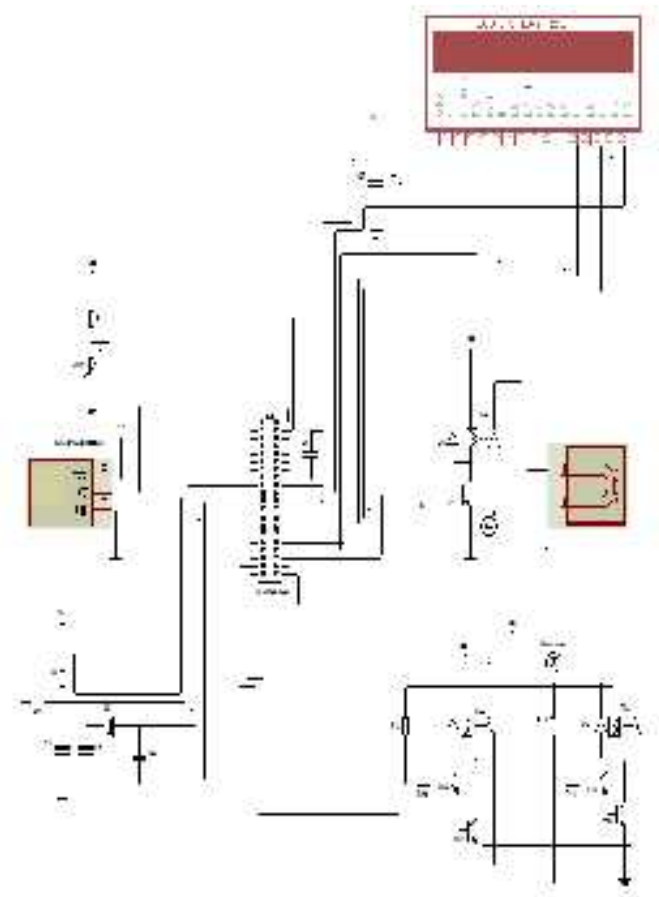

Gambar 3.2 Gambar Rangkaian

HASIL DAN PEMBAHASAN

Tabel 4.1 Data Pengukuran NTC47D15

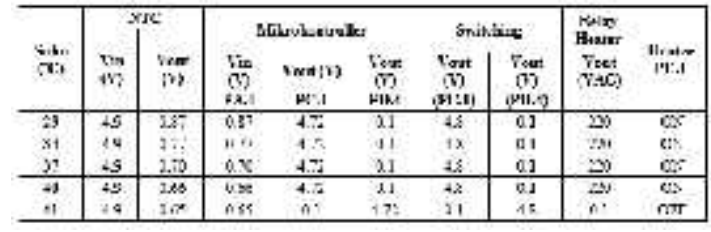

Tabel 4.2 Data Pengukuran Sensor $808 H 5$ V5

\begin{tabular}{|c|c|c|c|c|c|c|c|c|c|c|}
\hline \multirow[b]{2}{*}{ 10 } & \multirow[b]{2}{*}{$\begin{array}{l}\text { H } \\
\text { sio }\end{array}$} & \multicolumn{2}{|c|}{ SSS1PS } & \multicolumn{3}{|c|}{ Nuninemist } & \multicolumn{2}{|c|}{ mestabxi } & \multirow{2}{*}{ 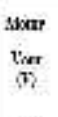 } & \multirow[b]{2}{*}{$\begin{array}{l}\text { Phen } \\
\text { O.e }\end{array}$} \\
\hline & & ais & No & $\begin{array}{l}i_{k} h \\
m_{i}\end{array}$ & $\begin{array}{c}\text { Tent? } \\
\text { ws }\end{array}$ & $\begin{array}{c}v_{r r} \\
i \\
v_{2}\end{array}$ & $\begin{array}{c}\text { Vher } \\
3\rangle \\
\text { WW } 51\end{array}$ & $\begin{array}{l}\text { Vermu } \\
\text { gent }\end{array}$ & & \\
\hline y & ㄱ. & 40 & 38 & ?:? & $n$ & 12 & $1 ?$ & $m$ & $2 ?$ & Tetrmi \\
\hline W & (1) & $4 y$ & $\therefore 1$ & $2: 1$ & 32 & 62 & 22 & 믄 & 22 & Ietras \\
\hline Nin & $\$ 5$ & $4 \%$ & is & 26 & 23 & $c$ & 22 & 02 & 22 & Ietro \\
\hline IIS & II & 24 & 30 & 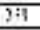 & 21 & $1 i$ & 32 & $1 i$ & 11 & Trisk \\
\hline
\end{tabular}

Ket : $\mathrm{t}=$ waktu $; \mathrm{H}=$ Kelembaban

\section{Pembahasan}

Berdasarkan data pada tabel 4.1 diketahui bahwa jika suhu yang terdeteksi NTC naik dari $29^{\circ} \mathrm{C}-40^{\circ} \mathrm{C}$, 
maka Vout mengalami penurunan hingga $0.66 \mathrm{~V}$, pada keadaan ini heater ON. Pada suhu $>40^{\circ} \mathrm{C}$ Vout $=0.65 \mathrm{~V}$, pada keadaan ini heater OFF. Untuk melihat hubungan antara suhu dan Vout dari sensor NTC dapat dilihat pada grafik gambar 4.1 berikut:

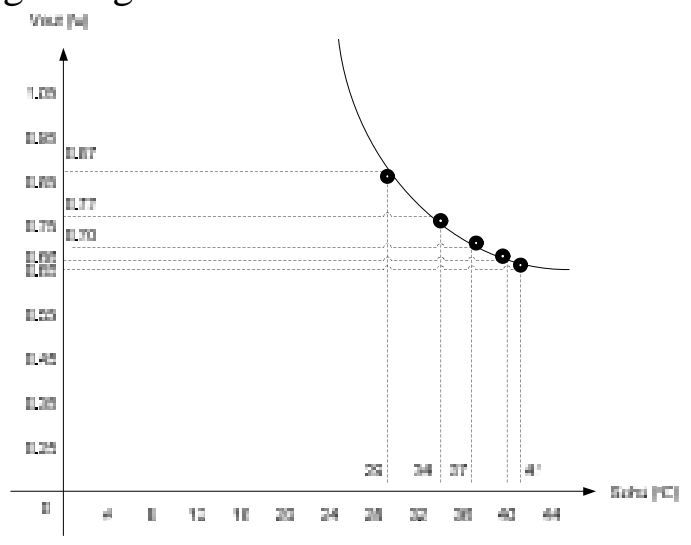

Gambar 4.1 Grafik Hubungan antara

Suhu terhadap Vout Sensor NTC

Dari grafik pada gambar 4.1 dapat diketahui bahwa semakin besar suhu yang terdeteksi maka akan semakin kecil nilai Vout yang dihasilkan, sehingga jelas bahwa perubahan suhu akan berbanding terbalik dengan Vout yang dihasilkan dari sensor NTC.

Sedangkan untuk sensor kelembaban berdasarkan data pada tabel 4.2 diketahui bawa kondisi awal daun sungkai saat dimasukkan kedalam oven memiliki kelembaban sebesar 70\% dengan Vout dari sensor 808H5V5 $\approx$ $2.86 \mathrm{~V}$.

Untuk kelembaban $65 \%$ Vout $=$ $2.73 \mathrm{~V}, 60 \%=2.54 \mathrm{~V}, 55 \%=2.40 \mathrm{~V}$ dan untuk $51 \%=2.33 \mathrm{~V} .51 \%$ merupakan kelembaban minimum yang terdeteksi oleh sensor kelembaban 808H5V5, sehingga apabila kelembaban telah mencapai level tersebut maka proses pengeringan akan terhenti dan pintu oven akan membuka.

Hubungan antara kelembaban dengan Vout sensor kelembaban 808H5V5 dapat dilihat pada grafik gambar 4.2 berikut:

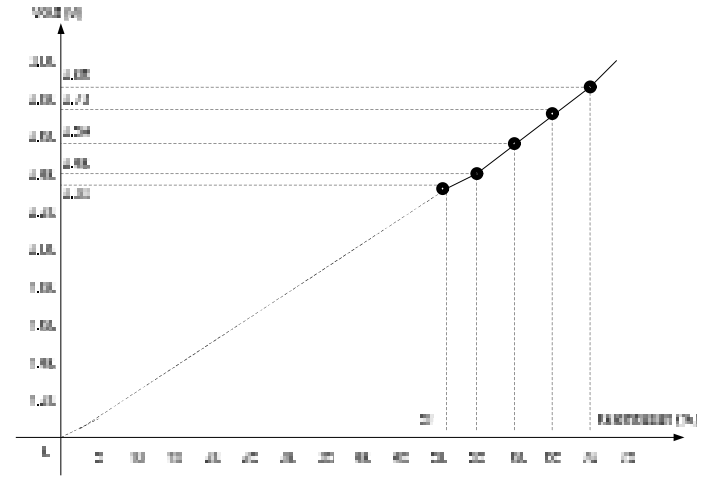

Gambar 4.2 Grafik Hubungan antara Kelembaban terhadap Vout Sensor Kelembaban 808H5V5

Dari grafik gambar 4.2 diketahui bahwa besarnya perubahan kelembaban akan berbanding lurus dengan Vout dari sensor kelembaban 808H5V5, sehingga semakin besar persentase kelembaban maka semakin besar pula Vout dari sensor kelembaban 808H5V5.

Kelembaban minimum yang terdeteksi adalah sebesar 51\%, maka disetting nilai set point Analog Digital Converter (ADC) pada program menjadi $2,33 \mathrm{VDC}=51 \%$ sehingga proses pengeringan berhenti dan pintu oven membuka. Apabila nilai ADC di-setting $<51 \%=2,33 \mathrm{VDC}$, maka akan terjadi proses pengeringan secara terus-menerus yang akan mengakibatkan simplisia menjadi rusak.

\section{KESIMPULAN}

1. Prinsip kerja NTC dipengaruhi oleh kenaikan suhu dimana pada suhu $29^{\circ} \mathrm{C}$ Vout $=0.87 \mathrm{~V}, 34^{\circ} \mathrm{C}=0.77 \mathrm{~V}$, $37^{\circ} \mathrm{C}=0.70 \mathrm{~V}$ dan $40^{\circ} \mathrm{C}=0.66 \mathrm{~V}$. Semakin meningkatnya suhu semakin menurun nilai tegangan output sensor. Apabila suhu yang dideteksi NTC > $40^{\circ} \mathrm{C}$, maka mikrokontroler akan menginstruksikan rangkaian switching untuk meng-OFF-kan heater.

2. Sensor kelembaban 808H5V5 mendeteksi kelembaban daun Sungkai selama proses pengeringan dimana 
keadaan awal yang terdeteksi adalah $70 \% \approx 2.86$ V. Kelembaban menurun seiring meningkatnya suhu, untuk kelembaban $65 \%$ Vout $=2.73 \mathrm{~V}, 60 \%$ $=2.54 \mathrm{~V}, 55 \%=2.40 \mathrm{~V}$ dan untuk $51 \%$ $=2.33 \mathrm{~V}$.

3. Nilai set point ADC yang di-setting pada program adalah $51 \%=2.33 \mathrm{~V}$, sehingga proses pengeringan berhenti dan pintu oven membuka.

\section{DAFTAR PUSTAKA}

Syahrul. 2012. Mikrokontroler AVR ATMEGA 8535. Bandung: Informatika

http://elektronikadasar.org/mengetahuifungsi-transistor-sebagai-saklar/ diakses pada 14 Juli 2013, pukul 12.35

http://elektronika-dasar.web.id/wpcontent/uploads/2012/01/Termistor.jpg diakses pada 3 Juli 2013 pukul 21.15 http://elektronikadasar.web.id/komponen/sensortranducer/sensor-suhu-termistor/, diakses pada 3 Jui 2013 pukul 21.15

http://elektronika-dasar.web.id/teorielektronika/daerah-saturasi-transistor/ diakses pada 14 Juli 2013, pukul 12.35 http://farmasibahanalam.files.wordpress. com/2010/08/5-a-penyiapan-bahanbaku-16-25.pdf, diakses pada 20 Juli 2013 http://id.wikipedia.org/wiki/Transistor, diakses pada 14 Juli 2013, pukul 12.35 http://www.ehow.com/facts_7492418_nt c-thermistor-work.html, diakses pada tanggal 14 Juli 2013, pukul 23.30

http://www.gemcs.com/download/appno tes/ntcn es.pdf, diakses pada 3 Juli2013 pukul 21.15

http://telinks.com/tag/relay-spdt/ diakses pada tanggal 15 Juli 2013 pukul 21.00

http://www.scribd.com/doc/139099985/ Sensor-Kelembaban diakses pada 14 juli 2013 pukul 00:13
http://www.scribd.com/doc/97291557/P ower-Window diakses pada tanggal 4 Juli 2013 pukul 22.30

id.wikipedia.org/wiki/transistor_darlingt on, tanggal 15 Juli 2012, pukul 00.11 www.elemenpemanas.co.id diakses pada tanggal 7 juli 2013 pukul 14.35

www.meriwardanaku.com diakses pada tanggal 11 Juli pukul 17.30 
ISSN :2085-6989

\section{HALAMAN INI SENGAJA DIKOSONGKAN}

